\title{
Evidence of price discovery on the Indonesian stock exchange
}

\author{
Susan Sunila Sharma ${ }^{\mathrm{a}}$, Kannan Thuraisamy ${ }^{\mathrm{a}}$, Muhammad Madyan ${ }^{\mathrm{b}, *}$, Nisful Laila ${ }^{\mathrm{b}}$ \\ ${ }^{a}$ Centre for Financial Econometrics, Deakin Business School Deakin University, 221 Burwood Highway Burwood, Victoria, 3125, Australia \\ ${ }^{\mathrm{b}}$ Faculty of Economics and Business, Universitas Airlangga, JI. Airlangga 4 Surabaya, Indonesia
}

A R T I C L E I N F O

This paper was handled by Associate Editor, Professor Chun-Ping Chang.

\section{Keywords:}

Indonesia

Stock market

Credit risk

Price discovery

\begin{abstract}
A B S T R A C T
The Indonesian stock market is emerging and very little is known about price discovery mechanisms. This paper addresses this research gap by compiling and utilizing a unique stock-level dataset (consisting of 342 stocks) to examine existence and behaviour of price discovery processes. Using the Indonesian sectoral spot price index, and the Bloomberg Markit iTraxx Asia and the CDX high yield index, we test for price discovery. Our findings suggest that pricing behaviour on Indonesian stock exchange is contributed by the credit risk market. We also note that our findings are robust to a different measure of credit risk.
\end{abstract}

\section{Introduction}

Recent studies (see Westerlund et al., 2017 and Narayan et al., 2018) have examined how price discovery in the stock exchanges evolves vis-à-vis the futures market and/or other prices. Understanding price discovery has been a subject of intense research over the last decade or so, and with the advent of good quality datasets the pursuit in understanding price discovery has continued to progress impressively. In this paper, we join recent studies investigating price discovery in emerging markets by considering Indonesia - a market about which very little is known from a price discovery perspective. In this regard, as we review below, Hande et al. (2018) is an exception. We investigate price discovery and start with an acknowledgement that our work is preliminary and will, therefore, set the foundation for additional work on Indonesia's stock exchanges. We have stock level price data for 342 firms. The dataset is unique because this sample-treatment has not been previously attempted to understand Indonesia's asset pricing. With our sample, these firms belong to eight sectors. We ask whether these prices contribute to pricing behaviour of the Markit iTraxx Asia index (MIAI, and, in robustness tests, a global CDX high yield (CDX HI) index). The MIAI is an index consisting of 40 (excluding Japan) which are considered the most liquid Asian entities with investment grade credit ratings.

The motivation for considering Indonesian spot prices against the Asian investment grade credit ratings (and global ratings) is as follows. First, the Indonesian economy, currently the 8th largest economy, is expected to grow in size and scale to become the fourth largest economy in 2050, replacing Japan which is presently the fourth largest economy in the world. ${ }^{1}$ Despite this prediction, the Indonesian stock market is fragile and is at a nascent stage of development (see, Sharma et al., 2019). Given the significant position the country is going to occupy as the fourth largest economy in three decades, deepening the understanding of the equity market representing the asset factor in terms of price discovery with particular emphasis on how it is linked to the regional and global credit series. Second, apart from the theoretical link between stock market and credit risk under the structural models of default, the spot prices and the credit risk series are empirically linked in the long-run. They have been shown to share long-run (cointegrating) relationships (see Section III). This means that one price can influence another. It is this relation which drives the price discovery mechanism. Essentially, it is a question of about which of the two markets contribute to price discovery. The point is that if two markets move together over a long-run period then they should (or at least one of them should) correct any disequilibrium in prices resulting in another market. Third, Narayan et al. (2016) show that price discovery is useful in predicting asset returns. They show that this predictability can be tracked by investors in devising successful investment strategies. The message is that as long as price discovery can be ascertained to be emerging from a market (say A) that market will have information content. Just because market A can contribute to price discovery in say market B, market A immediately becomes a source of information. Investors can thus utilize the

\footnotetext{
* Corresponding author. Faculty of Economics and Business, Universitas Airlangga, JI. Airlangga 4 Surabaya, Indonesia.

E-mail addresses: s.sharma@deakin.edu.au (S.S. Sharma), sivananthan.thuraisamy@deakin.edu.au (K. Thuraisamy), muhammadmadyan@gmail.com (M. Madyan), nisful.laila@feb.unair.ac.id (N. Laila).

1 Pricewaterhouse Coopers (2017) The long view: How will the global economic order change by 2050 ?.
} 
information content in market A to predict what will happen in market B. This leads us to our definition of price discovery. It is consistent with the concept of Granger causality-where one market's price Granger causes the other market's price-and consistent also with recent literature where the definition of price discovery has been coined to measure evidence of information content (see Narayan et al., 2016). This paper also relates to the recent studies that focus on the Indonesian economy in general and financial markets specifically (see, for example, Risvi et al., 2019; Narayan et al. 2019; Sharma, 2019; Thuraisamy, 2019).

Our dataset is a rich panel of firms having pricing data over time. This dataset is compiled specifically to test the hypothesis that price discovery exists in these two markets. The panel data set requires a panel price discovery methodology. The well-known and widely used price discovery methods of Hasbrouch (1995) and Granger and Gonzalo (GG, 1995) are time-series approaches. Recently, Karabiyik et al. (2018) developed a panel version of the Hasbrouch and GG tests, which are ideal given our research question. This panel price discovery method has been used to study price discovery in spot and futures markets by Hande et al. (2018). We apply the panel versions of the price discovery tests and show that price discovery in the Indonesian spot market is contributed by the MIAI. This is a fresh revelation because Indonesia does not have an active futures market. The closest market that Indonesian investors can access is the Asian market (MIAI). We show this to be the case because whatever happens in that market has price discovery implications for the Indonesian stock exchange. We show that these results are robust to a different measure of credit risk.

Our study contributes to recent attempts to understand price discovery. In this literature, the study that comes closest to our inquiry is Hande et al. (2018), who test for price discovery in 19 countries including Indonesia. They utilize monthly stock level price data and test whether it contributes to price discovery on the corresponding country-specific futures price. In the case of Indonesia, they use the SGX MSCI Indonesian Futures Index and their sample includes 49 stocks. They show that the Indonesian spot market dominates the price discovery process. We extend this analysis to, consistent with the proposal of Narayan et al. (2014), testing whether price discovery exists when the Indonesian spot market is pitched against credit risk markets. Our motivation is strong and rooted in both theory and practice; see Section II.

Our second contribution is to the literature on Indonesia's stock market. Indonesia is an emerging market about which there is limited research. The literature that exists can be summarized as follows. The comovement of Indonesia's stock market has been tested by Jiang et al. (2017). They show strong relation between Indonesian stock prices to those of Thailand and the Philippines. This evidence is corroborated in the work of Korkmaz et al. (2012). Volatility of Indonesia's stock market is demonstrated by Henker and Husodo (2010). Stock market convergence has been tested by Chien et al. (2015), who show that Indonesia's stock market adjusts to shocks to its own market and not to other ASEAN markets. Rhee and Wang (2009) show that foreign institutional ownership negatively affects Indonesia's stock market liquidity. The effect of Ramdan on Indonesia's stock market is shown to have a positive effect on liquidity by Lai and Windawati (2017). Effects on liquidity from merges have been studied by Yang and Pangastuti (2016), who show that large market capitalized firms and non-financial sector firms are more efficient post-merger. Finally, on the trading front, studies have demonstrated that technical trading rules are successful on the Indonesian stock exchange (see Yu et al., 2013; Ming-Ming and Siok-Hwa, 2006; Hart et al., 2003). Our study adds a fresh insight on Indonesia's stock exchange by showing how it is related to the credit markets, both regionally and globally. We demonstrate that whatever happens to pricing behaviour on Indonesia's stock market is dictated by the events in the credit market. Against this background, we proceed with the paper by first discussing the methodology (section II). Our method is based on a new/recent price discovery model proposed by Karabiyik et al. (2018), which allows us model panels of stocks. We then discuss the data and results in Section III. A uniqueness of our study is the new dataset we compile. We have a panel of 342 stocks. It makes for an insightful analysis of price discovery. The results proceed from preliminary statistics - about descriptive statistics of data, unit roots, and cointegration-to price discovery and economic implications. The contents of Section IV reflect concluding remarks.

\section{Further motivation and methodology}

This section sets out to achieve two goals. First is to develop the motivation for a credit-risk-equity market analysis of price discovery. Second is to explain our panel data approach to computing price discovery.

\subsection{Motivation}

When the subject is credit risk and equity market, the inspiration comes from Merton's (1974) structural model of credit risk. His work established the foundation to study the relation between credit risk and equity prices. From Merton's model, we learn that the co-movement of credit risk and equity prices is essential to eliminate arbitrage. Kapadia and $\mathrm{Pu}$ (2012) give prominence to this line of thought by claiming that the credit risk and equity market integration evolves with greater liquidity. It follows, and as Narayan (2015) and Narayan et al. (2014) argue and show, an upshot of the Merton model is a possible cointegrating relationship between credit risk and equity prices.

Inspired by the Merton model, a separate body of literature has evolved that tests the credit risk market and equity market nexus. One branch of this literature, which is closest to our proposal, examines the bivariate relationship between credit risk (CDS spread) and stock returns. The empirical evidence from this literature seems mixed. Some studies show that CDS leads the stock market (see Acharya and Johnson, 2007; Narayan et al., 2014) while others find that the stock market leads the CDS market (Norden and Weber, 2009; Forte and Pena, 2009). In a recent paper, Narayan (2015) shows that CDS return shocks are instrumental in explaining between 22 and $28 \%$ of the sectoral equity returns during crises times. His empirical evidence shows strong spillover effects from the CDS market to the equity market.

Against this background, using panel unit root and cointegration tests, we attempt to establish integration and cointegration relation between credit risk market and Indonesian stock prices.

\subsection{Econometric model}

Our test for price discovery is based on the following vector error correction regression model:

$$
\begin{gathered}
\left(\begin{array}{c}
\Delta S P_{i, t} \\
\Delta C D S_{i, t}
\end{array}\right)=\left(\begin{array}{c}
\alpha_{S P, i} \\
\alpha_{C D S, i}
\end{array}\right)\left(\beta_{S P, i} \beta_{C D S, i}\right)\left(\begin{array}{c}
S P_{i, t-1} \\
C D S_{i, t-1}
\end{array}\right) \\
+\sum_{\rho=1}^{k}\left(\begin{array}{cc}
\alpha_{1, i, \rho} & \alpha_{3, i, \rho} \\
\alpha_{2, i, \rho} & \alpha_{4, i, \rho}
\end{array}\right)\left(\begin{array}{c}
\Delta S P_{i, t-\rho} \\
\Delta C D S_{i, t-\rho}
\end{array}\right)\left(\begin{array}{c}
\varepsilon_{S P, i, t} \\
\varepsilon_{C D S, i, t}
\end{array}\right)
\end{gathered}
$$

In this regression, $\triangle S P$ and $\triangle C D S$ represent, respectively, the stock price returns for each stock $i$ and CDS index price returns. Several assumptions are in order. First, the price series (SP and CDS) are assumed to be non-stationary. Second, SP and CDS are expected to be cointegrated, such that the difference between the prices $\left(S P_{i, t}-C D S_{i, t}\right)$ is stationary. This implies that $\beta_{S P, i}=1$ and $\beta_{C D S, i}=-1$. Equation (1), according to the Granger representation theorem (see Engle and Granger, 1987), has a common trends representation of the following form:

$$
\begin{aligned}
& \Delta S P_{i, t}=A_{i}^{+}\left(\alpha_{S P, i, \perp} \sum_{s=1}^{t} \varepsilon_{S P, i, t}+\alpha_{C D S, i, \perp} \sum_{s=1}^{t} \varepsilon_{C D S, i, t}\right)+\sum_{\rho}^{\infty} \pi_{S P, \rho} \varepsilon_{S P, i, t} \\
& +\sum_{\rho}^{\infty} \pi_{S P C D S, \rho} \varepsilon_{C D S, i, t}+\tau_{S P, i, 0}
\end{aligned}
$$




$$
\begin{aligned}
& \Delta C D S_{i, t}=A_{i}^{+}\left(\alpha_{S P, i, \perp} \sum_{s=1}^{t} \varepsilon_{S P, i, t}+\alpha_{C D S, i, \perp} \sum_{s=1}^{t} \varepsilon_{C D S, i, t}\right)+\sum_{\rho}^{\infty} \pi_{C D S S P, \rho} \varepsilon_{S P, i, t} \\
& +\sum_{\rho}^{\infty} \pi_{C D S, \rho} \varepsilon_{C D S, i, t}+\tau_{C D S, i, 0}
\end{aligned}
$$

Here, $\pi_{S P, \rho}, \pi_{S P C D S, \rho} \pi_{C D S S P, \rho}$, and $\pi_{C D S, \rho}$ are functions of the parameters of the error correction model and $\tau_{S P, i, 0}$ and $\tau_{C D S, i, 0}$ are initial values. The point of this representation is that the stock price and credit market contain a random walk such that the effect of a shock to one of the market is permanently felt in both markets. This is captured by $\alpha_{S P, i, \perp}$ and $\alpha_{C D S, i, \perp}$. The information share measure of price discovery as proposed by Hasbrouck (1995) follows this representation. To see this, let us define the covariance matrix for the errors as:

$E\left[\begin{array}{cc}\varepsilon_{S P, i, t}^{2} & \varepsilon_{S P, i, t} \varepsilon_{C D S, i, t} \\ \varepsilon_{S P, i, t} \varepsilon_{C D S, i, t} & \varepsilon_{C D S, i, t}^{2}\end{array}\right]=\left[\begin{array}{cc}\omega_{S P, i} & \omega_{S P C D S, i} \\ \omega_{S P C D S, i} & \omega_{C D S, i}\end{array}\right]=\boldsymbol{\Omega}_{i}$

It is now easy to see the total variance of the effect of innovations that have a permanent effect on prices, which is: $\left(A_{i}^{+}\right)^{2} \alpha_{i, \perp}^{\prime}=\Omega_{\mu, i} \alpha_{i, \perp}$. According to the "Cholesky decomposition" of $\Omega_{i}$, we have $\Omega_{i}=C_{i} C_{i}$, where $C_{i}$ is a lower triangular matrix. The information share (IS) of CDS prices in the stock market is given by:

$I S_{C D S, S P}=\frac{\left(\alpha_{C D S, \perp}^{\prime} C_{i} \tau_{S P}\right)^{2}}{\alpha_{C D S, \perp}^{\prime} \Omega_{i} \alpha_{C D S, \perp}}$

The second measure of price discovery owes to GG and is based on a permanent-transitory decomposition of the prices. The price discovery of each market (SP \& CDS) is defined as:

$P T_{S P, i, j}=\frac{\alpha_{S P, i, \perp}}{\alpha_{S P, i, \perp}+\alpha_{C D S, i, \perp}}$

And

$P T_{C D S, i, j}=\frac{\alpha_{C D S, i, \perp}}{\alpha_{S P, i, \perp}+\alpha_{C D S, i, \perp}}$

Hande et al. (2018) develop panel versions of these price discovery measures by proposing a new estimator of $\alpha$, which has the following form:

$\widehat{\alpha}_{i}=\Delta \operatorname{PRICE}_{i}^{\prime} M_{\triangle P R I C E, i,-} \operatorname{PRICE}_{i,-1}^{*}\left[\left(\right.\right.$ PRICE $\left._{i,-1}^{*}\right){ }^{\prime} M_{\triangle P R I C E, i,-L}$ PRICE $\left._{i,-1}^{*}\right]$

where $M_{\triangle P R I C E, i,-L}=I_{t}-\triangle P R I C E_{i,-L}\left(\triangle P R I C E_{i,-}^{\prime} \Delta P R I C E_{i,-L}\right)^{-1} \Delta P R I C E_{i,-L}^{\prime}$. The mean group estimator of $\alpha$ is simply the average $\widehat{\alpha}_{i}$, where $L$ is the number of lags (for further details, see, Karabiyik et al., 2018 ${ }^{2}$ ).

\section{Data and results}

The aim of this section is to explain our dataset and results. We first explain data.

\footnotetext{
${ }^{2}$ One of the referees highlighted that equity and credit risk markets can be affected by a common factor and it should not be ignored. We would like to make a note that the model developed by Karabiyik et al. (2018) do not include a common factor in their price discovery framework. This can be considered as one of the limitations of the VECM based frameworks. This is further argued and explained by Westerlund et al. (2017) where they have developed a factor analytical approach to price discovery in a panel set-up. We have not adopted the approach proposed by Westerlund et al. (2017) and will leave this to be considered for future research.
}

\subsection{Data}

Our dataset includes 342 firms spanning 10 years (2008 - 2018), covering eight sectors, namely, utility, technology, materials, industrial, financial, energy, consumer non-cyclical, and communications. The number of firms ranges from 2 (utility) to 97 (financial). The Indonesian stock price data for each of these 342 firms is extracted from Bloomberg. In addition, we also utilise two credit market from Bloomberg, namely the MIAI index and the CDX HI index as the credit market proxies. The MIAI index is the credit derivative index for Asia and includes 40 of the most liquid Asian entities with investment grade credit rating (excluding entities domiciled in Japan). The CDX HI is the North American index covers 100 entities with high yield rating.

A plot of both indices is provided in Fig. 1. The two credit risk markets seem different from each other, implying a suitable test for robustness.

\section{Results}

\subsection{Preliminary evidence}

Some selected descriptive statistics are reported in Table 1. Panel A has mean, standard deviation, skewness, and kurtosis of credit risk variables and sectoral price returns. The CDX HI is more volatility than MIAI, and five times more positively skewed with a more leptokurtic distribution. Both credit risk variables are non-normal. The sectoral returns appear heterogenous consistent with sectoral return-based studies, such as Narayan et al. (2014) and Narayan (2015) for the US data. Indonesian data seems to have a similar behaviour. Three (utility, energy, and communication) sectoral returns have a negative return while the rest have a positive return. Volatility likewise is sector-specific. Two sectoral returns (utility and material) have negative skewness while the others have a positive skewness. All sectors have a leptokurtic distribution with some energy and material sectors more leptokurtic than others. The excess kurtosis reported found in the energy sector is attributable to the volatility in the energy sector following the sharp decline in the oil price during the sample period. Overall, sector heterogeneity is obvious, implying that how they relate to the credit markets are likely to be heterogenous as well.

The unconditional correlations are reported in Panel B. Sectoral returns and MIAI for all sectors share a negative correlation. All correlations are statistically different from zero with a t-statistic across sectors in the -8.55 to -36.48 range. On the other hand, sectoral price returns and CDX HI mostly have a positive unconditional correlation. In the case of material and industrial sectors while the correlation is negative it is also statistically insignificant. So, the overall message from unconditional correlations is that the MIAI index (the regional CDX market) is more significantly correlated to Indonesian stock market than the global CDX.

\subsection{Unit root and cointegration}

The Hadri (2000) panel unit root test examines the null hypothesis that each panel price series is stationary. For all three-price series (MIAI, $\mathrm{CDX} \mathrm{HI}$, and stock price) the null hypothesis is rejected at the $5 \%$ level or better in all eight panels (see Table 2). Larsson et al. (2001) panel cointegration test modelled on Johansen, 1995 time-series versions suggest strong evidence that CDS and stock prices in each of the 9 sectors are cointegrated (refer Table 3 ). This paves the way for us to test for price discovery, which we do next.

\subsection{Price discovery results}

The statistical significance of $\alpha_{C D S}$ (when it is less than 0) suggests that the credit market is contributing to any disequilibrium in stock returns. When $\alpha_{S P}>0$ and statistically significant it implies that the stock market is contributing to disequilibrium in the credit risk price returns. It follows, therefore, that GG1 indicates the extent of price discovery in the 


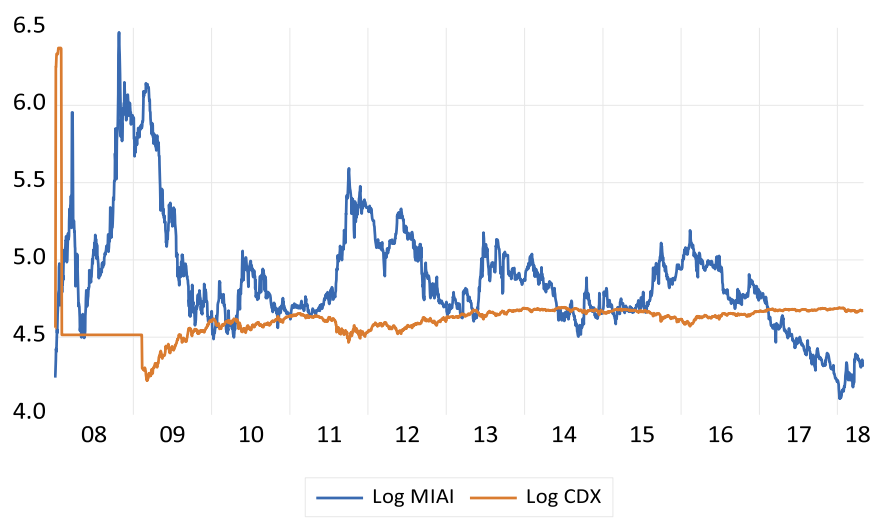

Fig. 1. A time-series plot of credit risk price series. This figure plots the timeseries data for the log of the Markit iTraxx Asia index (MIAI) and the global CDX high yield index.

credit risk market contributed by the stock market. In other words, GG1 and HAS1 give the percentage of price discovery in the credit risk market contributed by the stock market.

Judging the statistical significance of $\alpha_{C D S}$ and $\alpha_{S P}$ from Panel B of Table 4, the message about potential price discovery is clear. We see that $\alpha_{C D S}$ is statistically different from zero in all eight sectors with a $t$-statistic in the -3.75 to -36.81 range. This implies that the credit risk market contributes to price discovery in all sectoral prices. By comparison, $\alpha_{S P}$ is only statistically different from zero in three of the eight sectors. This implies that only consumer non-cyclical, financial, and industrial sectors prices contribute to price setting in the credit risk market.

Matching the significance of $\alpha_{S P}$ to the GG measure, we see that only in two (consumer non-cyclical and energy) of the eight sectors the price discovery is dominated by the Indonesian stock market, meaning that

Table 1

Descriptive statistics.

\begin{tabular}{|c|c|c|c|c|}
\hline \multicolumn{5}{|c|}{ Panel A: Descriptive statistics } \\
\hline & Mean & SD & Skew & Kurt \\
\hline \multicolumn{5}{|c|}{ Credit risk price return series } \\
\hline MIAI & 0.00 & 3.86 & 2.20 & 69.54 \\
\hline CDX HI & 0.00 & 4.31 & 11.36 & 1209.68 \\
\hline \multicolumn{5}{|l|}{ Price return series } \\
\hline Utility & -0.02 & 3.21 & -0.22 & 34.32 \\
\hline Technology & 0.00 & 3.39 & 0.85 & 22.29 \\
\hline Material & 0.01 & 3.90 & -1.75 & 284.14 \\
\hline Industrial & 0.01 & 3.22 & 0.60 & 35.22 \\
\hline Financial & 0.03 & 3.29 & 0.26 & 37.94 \\
\hline Energy & -0.02 & 3.82 & 7.82 & 628.23 \\
\hline Non_consumer & 0.04 & 3.04 & 0.51 & 25.46 \\
\hline Communication & -0.01 & 3.61 & 0.11 & 49.84 \\
\hline \multicolumn{5}{|c|}{ Panel B: Unconditional correlation } \\
\hline & \multicolumn{2}{|l|}{ MIAI } & \multicolumn{2}{|l|}{ CDX HI } \\
\hline & Coefficient & t-statistics & Coefficient & t-statistics \\
\hline Utility & $-0.119 * * *$ & -8.774 & 0.009 & 0.648 \\
\hline Technology & $-0.067 * * *$ & -8.552 & 0.004 & 0.557 \\
\hline Material & $-0.077^{* * *}$ & -25.096 & -0.0003 & -0.106 \\
\hline Industrial & $-0.079 * * *$ & -29.065 & -0.0003 & -0.115 \\
\hline Financial & $-0.071^{* * *}$ & -36.483 & $0.007^{* * *}$ & 3.767 \\
\hline Energy & $-0.084 * * *$ & -21.009 & $0.010^{* *}$ & 2.572 \\
\hline Non_consumer & $-0.088^{* * *}$ & -33.049 & $0.012^{* * *}$ & 4.309 \\
\hline Communication & $-0.074 * * *$ & -15.883 & 0.001 & 0.218 \\
\hline
\end{tabular}

This table reports selected descriptive statistics (the sample mean returns, standard deviation (SD), skewness (skew), and kurtosis (kurt)) in Panel A. Panel B of this table reports unconditional correlation between sectoral stock returns and returns on MIAI and CDX HI. The null hypothesis that the correlations are zero is also tested and the resulting t-statistics are reported. ** and *** denote statistical significance at $5 \%$, and $1 \%$ levels, respectively. prices of energy and consumer non-cyclical contribute between 64 and $68 \%$ of the price discovery in the credit risk market. However, because $\alpha_{S P}$ is statistically insignificant meaning that stock market is not contributing to any disequilibrium in the credit risk price returns, we conclude that only the consumer non-cyclical sector contributes to price discovery in the credit risk market.

Moreover, the industrial sector is the second most important-contributing $45.5 \%$ to price discovery while the financial sector contributes only $24.6 \%$. Overall, only these three sectors contribute to price discovery on the credit risk market. Based on the HAS1 test, however, evidence across all eight sectors suggests that price discovery is dominated by the credit risk market.

We now read results from Panel A where MIAI is used as a proxy for credit market. We see that of $\alpha_{C D S}<0$ and statistically significant in all eight sectors, implying that the MIAI contributes to price discovery in the Indonesia stock market. By comparison, $\alpha_{S P}>0$ in five (communication, consumer non-cyclical, energy, financials, and industrials) sectors, suggesting that in these sectors stock market also contributes to pricing behaviour of the MIAI. For four sectors, price discovery process is dominated (between $64 \%$ and $80 \%$ ) by the Indonesia stock market. Compared to using CDX HI as a proxy for credit risk, we find when using MIAI the role of the Indonesian stock market is stronger in the price discovery process. The reason seems obvious: the MIAI is an Asian index and Indonesian market is more closely associated to it rather than the North American credit market. Such relationship becomes stronger during equity market swing witnessed during the sample period.

\subsection{How robust are our results?}

Our main finding is that a search for price discovery between the Indonesia stock market and the credit risk market leads us to conclude that the price discovery process is dominated by the credit risk market. With our main empirical analysis, we have simultaneously been dealing with robustness. We have done so along two lines. First, we used two measure of panel price discovery. Both measures lead to the same conclusion that it is the credit risk market that is important in pricing discovery on the Indonesian stock exchange. Second, we have used two measures of credit risk. Both proxies for credit risk lead us to the same conclusion.

\section{Concluding remarks}

Indonesia's stock market is emerging and is at a nascent stage of development compared to other emerging markets. There is limited

Table 2

Panel tests for stationarity.

\begin{tabular}{llll}
\hline Sectors & MIAI & CDX HI & Stock Price \\
\hline Utility & $2.4399^{* *}(0.0073)$ & $1.8494^{* *}(0.0322)$ & $36.1641^{* * *}$ \\
& & & $(0.0000)$ \\
Technology & $4.2262^{* * *}$ & $3.2032^{* * *}$ & $54.2664^{* * *}$ \\
& $(0.0000)$ & $(0.0007)$ & $(0.0000)$ \\
Material & $10.7747^{* * *}$ & $8.1666^{* * *}$ & $101.369^{* * *}$ \\
& $(0.0000)$ & $(0.0000)$ & $(0.0000)$ \\
Industrial & $12.0773^{* * *}$ & $9.1539^{* * *}$ & $144.975^{* * *}$ \\
& $(0.0000)$ & $(0.0000)$ & $(0.0000)$ \\
Financial & $16.9925^{* * *}$ & $12.8793^{* * *}$ & $174.297^{* * *}$ \\
& $(0.0000)$ & $(0.0000)$ & $(0.0000)$ \\
Energy & $8.2744^{* * *}$ & $6.2715^{* * *}$ & $95.8347^{* * *}$ \\
& $(0.0000)$ & $(0.0000)$ & $(0.0000)$ \\
Non_consumer & $12.4415^{* * *}$ & $9.4299^{* * *}$ & $105.437^{* * *}$ \\
& $(0.0000)$ & $(0.0000)$ & $(0.0000)$ \\
Communication & $7.1137^{* * *}$ & $5.3918^{* * *}$ & $95.4753^{* * *}$ \\
& $(0.0000)$ & $(0.0000)$ & $(0.0000)$ \\
\hline
\end{tabular}

This table reports the Hadri (2000) panel unit root test results. We report the Hadri unit root test coefficient and its corresponding $p$-values in parenthesis. The null hypothesis is that the series follows a stationary process. Finally. *, **, and $* * *$ denote statistical significance at $10 \%, 5 \%$, and $1 \%$ levels, respectively. 
Table 3

Cointegration test results.

\begin{tabular}{|c|c|c|c|c|c|c|c|c|}
\hline \multirow[t]{2}{*}{ Sectors } & \multicolumn{2}{|l|}{ MIAI (trace test) } & \multicolumn{2}{|c|}{ MIAI (max-eigen test) } & \multicolumn{2}{|l|}{ CDX HI (trace test) } & \multicolumn{2}{|c|}{ CDX HI (max-eigen test) } \\
\hline & $r=0$ & $r=1$ & $r=0$ & $r=1$ & $r=0$ & $r=1$ & $r=0$ & $r=1$ \\
\hline Utility & $30.30 * * *(0.000)$ & $12.67 * *(0.013)$ & $\begin{array}{l}23.00 * * * \\
(0.0001)\end{array}$ & $12.67^{* *}(0.013)$ & $411.3^{* * *}(0.000)$ & $12.91 * *(0.012)$ & $73.31 * * *(0.000)$ & $12.91 * *(0.012)$ \\
\hline Technology & $152.1^{* * *}(0.000)$ & $20.06 *(0.066)$ & $76.77 * * *(0.000)$ & $20.06 *(0.066)$ & $\begin{array}{l}1113.0^{* * *} \\
(0.000)\end{array}$ & $\begin{array}{l}60.96^{* * *} \\
(0.000)\end{array}$ & $219.0^{* * *}(0.000)$ & $\begin{array}{l}60.96 * * * \\
(0.000)\end{array}$ \\
\hline Material & $\begin{array}{l}1224.0^{* * * *} \\
(0.000)\end{array}$ & $\begin{array}{l}238.9^{* * * *} \\
(0.000)\end{array}$ & $518.2^{* * *}(0.000)$ & $\begin{array}{l}238.9 * * * \\
(0.000)\end{array}$ & $\begin{array}{l}8472.0^{* * *} \\
(0.000)\end{array}$ & $\begin{array}{l}646.5^{* * *} \\
(0.000)\end{array}$ & $\begin{array}{l}1430.0 * * * \\
(0.000)\end{array}$ & $\begin{array}{l}646.5^{* * *} \\
(0.000)\end{array}$ \\
\hline Industrial & $895.4^{* * *}(0.000)$ & $\begin{array}{l}203.2^{* * *} \\
(0.000)\end{array}$ & $557.4 * * *(0.000)$ & $\begin{array}{l}203.2^{* * *} \\
(0.000)\end{array}$ & $\begin{array}{l}9886.0^{* * *} \\
(0.000)\end{array}$ & $\begin{array}{l}484.7^{* * *} \\
(0.000)\end{array}$ & $\begin{array}{l}1796.0^{* * * *} \\
(0.000)\end{array}$ & $\begin{array}{l}484.7 * * * \\
(0.000)\end{array}$ \\
\hline Financial & $\begin{array}{l}1439.0^{* * * *} \\
(0.000)\end{array}$ & $\begin{array}{l}462.1^{* * *} \\
(0.000)\end{array}$ & $\begin{array}{l}1074.0 * * * \\
(0.000)\end{array}$ & $\begin{array}{l}462.1^{* * *} \\
(0.000)\end{array}$ & $\begin{array}{l}20864^{* * *} \\
(0.000)\end{array}$ & $\begin{array}{l}531.1^{* * *} \\
(0.000)\end{array}$ & $\begin{array}{l}3555.0 * * * \\
(0.000)\end{array}$ & $\begin{array}{l}531.1^{* * *} \\
(0.000)\end{array}$ \\
\hline Energy & $348.8^{* * *}(0.000)$ & $\begin{array}{l}87.32^{* * *} \\
(0.000)\end{array}$ & $276.2^{* * *}(0.000)$ & $\begin{array}{l}87.32^{* * *} \\
(0.000)\end{array}$ & $4549 * * *(0.000)$ & $\begin{array}{l}127.6^{* * *} \\
(0.000)\end{array}$ & $834.1^{* * *}(0.000)$ & $\begin{array}{l}127.6^{* * *} \\
(0.000)\end{array}$ \\
\hline Non_consumer & $797.5^{* * *}(0.000)$ & $\begin{array}{l}172.6^{* * *} \\
(0.000)\end{array}$ & $541.9 * * *(0.000)$ & $\begin{array}{l}172.6^{* * *} \\
(0.000)\end{array}$ & $\begin{array}{l}10504^{* * *} \\
(0.000)\end{array}$ & $\begin{array}{l}251.7^{* * *} \\
(0.000)\end{array}$ & $\begin{array}{l}1906.0^{* * * *} \\
(0.000)\end{array}$ & $\begin{array}{l}251.7^{* * * *} \\
(0.000)\end{array}$ \\
\hline Communication & $425.1 * * *(0.000)$ & $\begin{array}{l}58.95^{* * *} \\
(0.005)\end{array}$ & $196.2^{* * *}(0.000)$ & $\begin{array}{l}58.95^{* * *} \\
(0.005)\end{array}$ & $\begin{array}{l}3329.0^{* * *} \\
(0.000)\end{array}$ & $\begin{array}{l}274.2^{* * *} \\
(0.000)\end{array}$ & $623.1 * * *(0.000)$ & $\begin{array}{l}274.2^{* * *} \\
(0.000)\end{array}$ \\
\hline
\end{tabular}

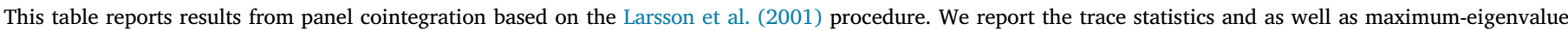
statistics for testing the null hypothesis of $r=0$ and $r=1$. Finally, ***, and $* * *$ denote statistical significance at $10 \%, 5 \%$, and $1 \%$ levels, respectively.

Table 4

Price discovery results.

\begin{tabular}{|c|c|c|c|c|c|c|c|c|}
\hline \multirow[t]{2}{*}{ Sectors } & \multicolumn{4}{|c|}{ Panel A: MIAI } & \multicolumn{4}{|c|}{ Panel B: CDX HI } \\
\hline & $\alpha_{C D S}$ & $\alpha_{S P}$ & GG1 & HAS1 & $\alpha_{C D S}$ & $\alpha_{S P}$ & GG1 & HAS1 \\
\hline Materials & $\begin{array}{l}-0.006^{* * *} \\
(-21.910)\end{array}$ & $\begin{array}{l}0.003 \\
(0.834)\end{array}$ & $\begin{array}{l}0.369 * * \\
(2.270)\end{array}$ & $\begin{array}{l}0.008 * * * \\
(47.510)\end{array}$ & $\begin{array}{l}-0.023 * * * \\
(-24.340)\end{array}$ & $\begin{array}{l}0.008 \\
(1.180)\end{array}$ & $\begin{array}{l}0.258 * * * \\
(4.610)\end{array}$ & $\begin{array}{l}0.004^{* * * *} \\
(134.870)\end{array}$ \\
\hline Communication & $\begin{array}{l}-0.006^{* * *} \\
(-12.360)\end{array}$ & $\begin{array}{l}0.012^{* *} \\
(2.440)\end{array}$ & $\begin{array}{l}0.659 * * * \\
(3.930)\end{array}$ & $\begin{array}{l}0.109 * * * \\
(11.820)\end{array}$ & $\begin{array}{l}-0.023^{* * *} \\
(-10.690)\end{array}$ & $\begin{array}{l}0.007 \\
(1.590)\end{array}$ & $\begin{array}{l}0.228 * * * \\
(6.490)\end{array}$ & $\begin{array}{l}0.004^{* * *} \\
(184.190)\end{array}$ \\
\hline $\begin{array}{l}\text { Consumer non- } \\
\text { cyclical }\end{array}$ & $\begin{array}{l}-0.005^{* * *} \\
(-25.900)\end{array}$ & $\begin{array}{l}0.022^{* * *} \\
(2.900)\end{array}$ & $\begin{array}{l}0.808^{* * *} \\
(3.640)\end{array}$ & $\begin{array}{l}0.030 * * * \\
(44.720)\end{array}$ & $\begin{array}{l}-0.022^{* * *} \\
(-29.400)\end{array}$ & $\begin{array}{l}0.040 * * * \\
(2.680)\end{array}$ & $\begin{array}{l}0.639 * * * \\
(4.290)\end{array}$ & $\begin{array}{l}0.008^{* * *} \\
(162.130)\end{array}$ \\
\hline Energy & $\begin{array}{l}-0.007 * * * \\
(-11.140)\end{array}$ & $\begin{array}{l}0.015^{* *} \\
(2.269)\end{array}$ & $\begin{array}{l}0.688^{* * *} \\
(3.200)\end{array}$ & $\begin{array}{l}0.015^{* * *} \\
(75.040)\end{array}$ & $\begin{array}{l}-0.020 * * * \\
(-20.240)\end{array}$ & $\begin{array}{l}0.042 \\
(1.540)\end{array}$ & $\begin{array}{l}0.679 * * \\
(2.260)\end{array}$ & $\begin{array}{l}0.019^{* * * *} \\
(40.360)\end{array}$ \\
\hline Financials & $\begin{array}{l}-0.006^{* * *} \\
(-29.460)\end{array}$ & $\begin{array}{l}0.003^{* * *} \\
(4.050)\end{array}$ & $\begin{array}{l}0.362^{* * *} \\
(11.010)\end{array}$ & $\begin{array}{l}0.009 * * * \\
(218.580)\end{array}$ & $\begin{array}{l}-0.024^{* * *} \\
(-36.810)\end{array}$ & $\begin{array}{l}0.008 * * * \\
(5.220)\end{array}$ & $\begin{array}{l}0.246 * * * \\
(20.410)\end{array}$ & $\begin{array}{l}0.004^{* * * *} \\
(590.230)\end{array}$ \\
\hline Industrials & $\begin{array}{l}-0.006^{* * *} \\
(-23.830)\end{array}$ & $\begin{array}{l}0.010^{* * *} \\
(3.280)\end{array}$ & $\begin{array}{l}0.635^{* * *} \\
(5.070)\end{array}$ & $\begin{array}{l}0.019 * * * \\
(75.740)\end{array}$ & $\begin{array}{l}-0.023^{* * *} \\
(-27.910)\end{array}$ & $\begin{array}{l}0.019 * * * \\
(2.760)\end{array}$ & $\begin{array}{l}0.455^{* * *} \\
(6.110)\end{array}$ & $\begin{array}{l}0.007^{* * *} \\
(198.420)\end{array}$ \\
\hline Technology & $\begin{array}{l}-0.005^{* * *} \\
(-8.590)\end{array}$ & $\begin{array}{l}0.003 \\
(1.430)\end{array}$ & $\begin{array}{l}0.379 * * * \\
(4.150)\end{array}$ & $\begin{array}{l}0.073^{* * *} \\
(10.710)\end{array}$ & $\begin{array}{l}-0.020 * * * \\
(-16.590)\end{array}$ & $\begin{array}{l}0.005 \\
(1.440)\end{array}$ & $\begin{array}{l}0.208^{* * *} \\
(7.500)\end{array}$ & $\begin{array}{l}0.020^{* * *} \\
(38.440)\end{array}$ \\
\hline Utility & $\begin{array}{l}-0.008^{* * *} \\
(-3.430)\end{array}$ & $\begin{array}{l}0.019 \\
(1.210)\end{array}$ & $\begin{array}{l}0.701 \\
(1.275)\end{array}$ & $\begin{array}{l}0.105^{* * *} \\
(4.270)\end{array}$ & $\begin{array}{l}-0.021^{* * *} \\
(-3.750)\end{array}$ & $\begin{array}{l}0.001 \\
(0.622)\end{array}$ & $\begin{array}{l}0.041 * * * \\
(12.930)\end{array}$ & $\begin{array}{l}0.0001 * * * \\
(>600)\end{array}$ \\
\hline
\end{tabular}

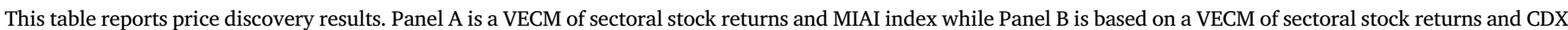
HI index returns. The panel versions of the GG and HAS results are reported. The HAS is the average of the lower and upper bounds of HAS. $\alpha_{C D S}$ $\left(\alpha_{S P}\right)$ denote statistical significance or otherwise of the error correction terms relating to when stock returns

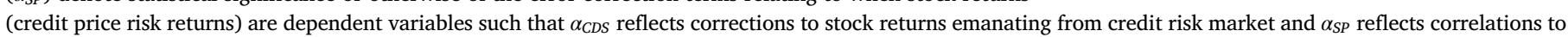

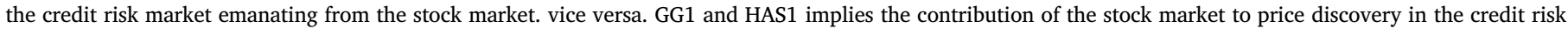
market. Finally, $* *$ and $* * *$ denote statistical significance at the $5 \%$ and $1 \%$ levels, respectively.

knowledge on price discovery mechanisms involving the Indonesian market. Motivated by the Merton model of credit risk, and several recent empirical work that test the relation between stock returns and credit risk, we propose to examine price discovery between the Indonesian stock market and the credit risk market which we proxy using the Asian (excluding Japan) credit derivative index that includes 40 most liquid Asian entities with investment grade credit ratings and the CDX HI North American index consisting of 100 stocks with high yield rating below BBB-. To test for price discovery, we compile a daily panel dataset on Indonesian stocks. This dataset has 342 stocks that belong to eight sectors. The time component of data is 02 January 2008 to 20 April 2018. We employ a panel data price discovery model which allow us to model panels of stocks. From this exercise, we show that the price discovery process on the Indonesian stock exchange is strongly contributed by the credit risk market. The policy implication arising from this study is that the regional and global credit risk factors potentially plays an important role influencing the equity risk premium in Indonesia.

\section{Appendix A. Supplementary data}

Supplementary data to this article can be found online at https://doi. org/10.1016/j.econmod.2019.09.005.

\section{References}

Acharya, V.V., Johnson, T.C., 2007. Insider-trading in credit derivatives. J. Financ. Econ. 84, 110-141.

Chien, M.-S., Lee, C.-C., Hu, T.-C., Hu, H.-T., 2015. Dynamic Asian stock market convergence: evidence from dynamic cointegration analysis among China and ASEAN-5. Econ. Modell. 51, 84-98.

Coopers, Pricewaterhouse, 2017. The Long View: How Will the Global Economic Order Change by 2050? https://www.pwc.com/gx/en/world-2050/assets/pwc-world-in -2050-summary-report-feb-2017.

Engle, R.F., Granger, C.W., 1987. Cointegration and error correction: representation, estimation and testing. Econometrica 251-276.

Forte, S., Pena, J.I., 2009. Credit spreads: an empirical analysis on the informational content of stocks, bonds, and CDS. J. Bank. Financ. 33, 2012-2025.

Gonzalo, J., Granger, C., 1995. Estimation of common long-memory components in cointegrated systems. J. Bus. Econ. Stat. 13, 27-35. 
Hadri, K., 2000. Testing for stationarity in heterogeneous panel data. Econom. J. 3 , $148-161$.

Hande, K., Narayan, P.K., Phan, D.H.B., Westerlund, J., 2018. Islamic spot and index futures markets: where is the price discovery? Pac. Basin Financ. J. 52, 123-133.

Hart, Jvd, Slagter, E., Dijk, D.V., 2003. Stock selection strategies in emerging markets. J. Empir. Financ. 10, 105-132.

Hasbrouck, J., 1995. One security, many markets: determining the contribution to price discovery. J. Financ. 50, 1175-1199.

Henker, T., Husodo, Z.A., 2010. Noise and efficient variance in the Indonesia stock exchange. Pac. Basin Financ. J. 18, 199-216.

Jiang, Y., Nie, H., Monginsidi, J.Y., 2017. Co-movement of ASEAN stock markets: new evidence from wavelet and VMD-based copula tests. Econ. Modell. 64, 384-398.

Johansen, S., 1995. Likelihood-Based Inference in Cointegrated Vector Autoregressive Models. Oxford University Press, Oxford, UK.

Kapadia, N., Pu, X., 2012. Limited arbitrage between equity and credit markets. J. Financ Econ. 105, 542-564.

Karabiyik, H., Westerlund, J., Narayan, 2018. Panel Data Measures of Price Discovery. Unpublished manuscript.

Korkmaz, T., Cevik, E.I., Atukeren, E., 2012. Return and volatility spillovers among CIVETS stock markets. Emerg. Mark. Rev. 13, 230-252.

Lai, Y.-W., Windawati, A., 2017. Risk, return and liquidity during Ramadan: evidence from Indonesian and Malaysian stock markets. Res. Int. Bus. Financ. 42, 233-241.

Larsson, R., Lyhagen, J., Lothgren, M., 2001. Likelihood-based cointegration tests in heterogeneous panels. Econom. J. 4, 109-142.

Merton, R., 1974. On the pricing of corporate debt: the risk structure of interest rates. J. Financ. 29, 449-470.

Ming-Ming, L., Siok-Hwa, L., 2006. The profitability of the simple moving averages and trading range breakout in the Asian stock markets. J. Asian Econ. 17, 144-170.

Narayan, P.K., 2015. An analysis of sectoral equity and CDS spreads. J. Int. Financ. Mark. Inst. Money 34, 80-93.
Narayan, S., Falianty, T., Tobing, L., 2019. The influence of oil prices on Indonesia's exchange rate. Bull. Mon. Econ. Bank. 21, 303-322.

Narayan, P.K., Sharma, S., Thuraisamy, K., 2014. An analysis of price discovery from panel data models of CDS and equity returns. J. Bank. Financ. 41, 167-177.

Narayan, P.K., Phan, D.H.B., Thuraisamy, K., Westerlund, J., 2016. Price discovery and asset pricing. Pac. Basin Financ. J. 40, 224-235.

Narayan, P.K., Sharma, S.S., Thuraisamy, K., Westerlund, J., 2018. Some preliminar evidence of price discovery in Islamic banks. Pac. Basin Financ. J. 52, 107-122.

Norden, L., Weber, M., 2009. The co-movement of credit default swap, bond and stock markets: an empirical analysis. Eur. Financ. Manag. 15, 529-562.

Rhee, S.G., Wang, J., 2009. Foreign institutional ownership and stock market liquidity: evidence from Indonesia. J. Bank. Financ. 33, 1312-1324.

Rizvi, S.A.R., Narayan, P.K., Sakti, A., Syarifuddin, F., 2019. Role of Islamic banks in Indonesian banking industry: an empirical exploration. Pac. Basin Financ. J. (in press).

Sharma, S.S., 2019. Which variables predict Indonesia's inflation? Bull. Mon. Econ. Bank. 22, 87-102.

Sharma, S.S., Narayan, P.K., Thuraisamy, K., Laila, N., 2019. Is Indonesia's stock market different when it comes to predictability? Emerg. Mark. Rev. (in press).

Thuraisamy, K.S., 2019. The Credit risk dynamics of international bonds: the Indonesian case. Bull. Mon. Econ. Bank. 21, 531-550.

Westerlund, J., Reese, S., Narayan, P.K., 2017. A factor analytical approach to price discovery. Oxf. Bull. Econ. Stat. 79, 0305-9047.

Yang, A.S., Pangastuti, A., 2016. Stock market efficiency and liquidity: the Indonesian stock exchange merger. Res. Int. Bus. Financ. 36, 28-40.

Yu, H., Nartea, G.V., Gan, C., Yao, L.J., 2013. Predictive ability and profitability of simple technical trading rules: recent evidence from Southeast Asian stock markets. Int. Rev. Econ. Financ. 25, 356-371. 